\title{
New records of Morid fishes (Teleostei: Gadiformes) from the southernmost tip of South America*
}

\author{
ROBERTO MELÉNDEZ ${ }^{1}$ and GERMÁN PEQUEÑO² \\ ${ }^{1}$ Museo Nacional de Historia Natural, Casilla 787, Santiago, Chile. \\ ${ }^{2}$ Instituto de Zoología. Universidad Austral de Chile, Casilla 567, Valdivia, Chile.
}

\begin{abstract}
SUMMARY: Three species of morid fishes were collected during the Expedition Antarktis XIII/4 of RV "Polarstern" at the southernmost tip of South America, on the slope east of Isla Nueva, Southern Chile ( $c a .55^{\circ}$ S), Antimora rostrata (Günther, 1878), Guttigadus kongi (Markle and Meléndez, 1988) and Lepidion ensiferus (Günther, 1887). Representing new records for the above area, all of them were previoulsy recorded from the Chilean and Argentinean Patagonian region.
\end{abstract}

Key words: Moridae, Chile, Southern Ocean.

RESUMEN: Nuevos Registros De PeCES De la familia Moridae (Teleostei: Gadiformes) DEl eXtremo sur de AmÉRICA DEL SUR. - Tres especies de peces de la Familia Moridae fueron recolectadas durante la Expedición Antarktis XIII/4 del B/I "Polarstern"en el talud continental, al este de Isla Nueva, Chile (ca. 55 S), Antimora rostrata (Günther, 1878), Guttigadus kongi (Markle y Meléndez, 1988) y Lepidion ensiferus (Günther, 1887), representando una ampliación en la distribución sur de las especies mencionadas. Todas ellas fueron previamente registradas para la región austral de América del Sur.

Palabras clave: Moridae, Chile, Océano Austral.

\section{INTRODUCTION}

Morid fishes include about 100 species, but they are poorly known (Cohen et al., 1990). Within morids the genus Antimora was reviewed by Small (1981). A revision of Lepidion from the North Atlantic was made by Templeman (1970). Nakaya et al. (1980) reviewed Lepidion from the north-western Pacific, and Paulin (1984) indicate new records of Lepidion species from New Zealand. Only Laemonema was recently the subject of a phylogenetic study in which this genus was split in two genera: Laemonema and Gutti-

\footnotetext{
*Accepted September 14, 1998.
}

gadus (Meléndez and Markle, 1997). Howes (1991) studied the biogeography of gadoid fishes and concluded that morid fishes have a wide vertical distribution, are mostly benthopelagic, and Antimora may reach $3000 \mathrm{~m}$ depth.

During the 1996 Expedition Antarktis XIII/4 of RV "Polarstern" cruise to the Antarctic, passing by the southernmost tip of South America, in May 1996 some specimens of the morid genera Antimora, Guttigadus and Lepidion were caught. These captures are commented in the present paper, as well as a short discussion on the ichthyogeographical significance of their presence on the eastern slope of Isla Nueva, southern Chile. 


\section{MATERIAL AND METHODS}

Fishes were collected in May 1996 by the Expedition Antarktis XIII/4-5 of RV "Polarstern" to the Antarctic, with an Agassiz trawl of $1.5 \mathrm{~m}$ width and $10 \mathrm{~mm}$ meshes in the codend. All specimens were fixed in $10 \%$ formaldehyde. Measurements and counts follow Templeman (1970) and Paulin (1983). Specimens are deposited at the Instituto de Zoología de la Universidad Austral de Chile (IZUA), the Museo Nacional de Historia Natural, Chile (MNHNC) and the Instituto de la Patagonia, Universidad de Magallanes, Chile. Abbreviation used: $\mathrm{Sl}=$ standard length.

\section{RESULTS}

Antimora rostrata (Günther, 1878): MNHNC P. 7086, 1 specimen, $119.8 \mathrm{~mm}$ Sl. East of Isla Nueva, southern Chile, 55 28.8'S, 66 03.4'W, 1005-1070 m depth. 17 May 1996. RV "Polarstern" sta. 40/111AGT. Measurements and counts are presented in Table 1.

Guttigadus kongi (Markle and Meléndez, 1988): IZUA-PM 2044. 2 specimens, 134.6-164.1 mm Sl. MNHNC P: 7087, $134.0 \mathrm{~mm} \mathrm{Sl}$, and Instituto de la Patagonia, uncatalogued, $134.6 \mathrm{~mm} \mathrm{S1,.}$ East of Isla

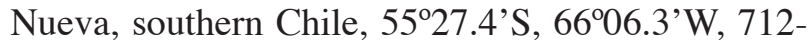
780 m depth. 18 May 1996. RV "Polarstern" sta. 40/115-AGT. Measurements and counts are presented in Table 1.

Lepidion ensiferus (Günther, 1887): MNHNC P 7088. 1 specimen, $233 \mathrm{~mm} \mathrm{Sl}$. East of Isla Nueva, southern Chile, $55^{\circ} 26.3^{\prime} \mathrm{S}, 6^{\circ} 13.5^{\prime} \mathrm{W}, 107 \mathrm{~m}$ depth. 16 May 1996. RV "Polarstern" sta. 40/110AGT. Measurements and counts are presented in Table 1.

\section{DISCUSSION}

All specimens fit with available descriptions (fide Günther, 1887; Small, 1981; Meléndez and Markle, 1997).

These fishes were caught in an area where the sea temperature showed a homogeneous distribution within the first $50 \mathrm{~m}$, between 7 and $8^{\circ} \mathrm{C}$. A thermocline was found between 50 and $100 \mathrm{~m}$. Below this layer, the temperature fluctuated from 5 to $6^{\circ} \mathrm{C}$ in the upper part to 2 and $3^{\circ} \mathrm{C}$ in the deeper part. Lepidion ensiferus was found living in the
TABLE 1. - Measurements (in \% Sl) and meristic counts for Antimora rostrata, Guttigadus kongi and Lepidion ensiferus from the East of Isla Nueva, southern Chile.

\begin{tabular}{|c|c|c|c|}
\hline & A. rostrata & G. kongi & L. ensiferus \\
\hline Standard length (mm) & 119.8 & 134.6-164.1 & 233 \\
\hline \multicolumn{4}{|l|}{ Measurements (in \% of S1) } \\
\hline Head length & 25.3 & $25.5-27.9$ & 20.6 \\
\hline Snout length & 8.9 & $8.1-8.9$ & 7.0 \\
\hline Interorbital width & 6.4 & $10.3-11.8$ & 4.2 \\
\hline Orbit diameter & 8.1 & $7.1-9.2$ & 7.5 \\
\hline Upper jaw length & 10.3 & $12.3-13.5$ & 8.4 \\
\hline Predorsal length & 26.5 & $28.4-31.7$ & 22.8 \\
\hline Preanal length & 55.3 & $39.9-42.6$ & 43.9 \\
\hline Caudal peduncle height & 3.5 & $2.2-2.6$ & 2.1 \\
\hline Barbel length & 2.4 & $0.7-1.9$ & 4.5 \\
\hline \multicolumn{4}{|l|}{ Meristic counts } \\
\hline First dorsal fin & 4 & $5-6$ & 6 \\
\hline Second dorsal fin & 52 & $67-75$ & 53 \\
\hline Anal fin & 41 & $65-66$ & 42 \\
\hline Pectoral fin & 20 & $23-25$ & 23 \\
\hline Pelvic fin & 6 & 5 & 7 \\
\hline Gill rakers & $11+4$ & $15-16+6-7$ & $12+5$ \\
\hline Gill filaments on first arch & 84 & - & - \\
\hline
\end{tabular}

lower layer of the thermocline with temperatures around $5^{\circ} \mathrm{C}$; Nakamura (1986) indicated that in the Argentinean Patagonian region where L. ensiferus was caught the water temperatures from 200 to $1000 \mathrm{~m}$ depth were 5 to $4^{\circ} \mathrm{C}$. The capture depths for $G$. kongi and A. rostrata were similar to those found for other specimens elsewhere. A. rostrata seems to live at greater depth.

The records described here were not surprising because of the wide distribution of A. rostrata and $G$. kongi in the Southern Ocean, however these species were never caught at the southernmost tip of South America before. Lepidion ensiferus was restricted to a narrow belt off Chile at $18^{\circ} 51^{\prime}$ 'S to 1903'S (Kong and Meléndez, 1991), and was known from the continental slope off Argentina (Cohen et al., 1990). Kong and Meléndez (1991) also reported another specimen of Lepidion from Chile ( $\left.32^{\circ} 13^{\prime} \mathrm{S}\right)$, but they adscribed it to a probable Lepidion microcephalus Cowper,1956. The new captures tend to show more continuity in the distribution of these species, which seem to form part of a belt with particular taxonomic composition in which gadiforms and zoarcids, among other groups, are important components.

If a visual comparison among species is needed, we recommend Cohen et al. (1990) for Lepidion ensiferus and Antimora rostrata and Chiu et al. (1990) for Guttigadus kongi. 


\section{ACKNOWLEGDEMENTS}

We thank Dr. Wolf Arntz (Alfred Wegener Institute for Polar and Marine Research) for his kind invitation to study the fishes of the RV "Polarstern" Expedition Antarktis XIII/4, Mr. Marco Lardies (Universidad Austral de Chile) for his effort in the capture of the fishes, and to project S-96-04, Universidad Austral de Chile.

\section{REFERENCES}

Chiu, T.S., D.F. Markle and R. Meléndez. - 1990. Moridae. Deepsea cods. In: O. Gon and P.C. Heemstra (eds), Fishes of the Southern Ocean, pp. 183-187. J.L.B. Smith Institute of Ichthyology, Grahamstown.

Cohen, D.M., T. Inada, T. Iwamoto and N. Scialabba. - 1990. FAO species catalogue. Vol. 10. Gadiform Fishes of the world (Order Gadiformes). An annotated and illustrated catalogue of cods, hakes, grenadiers and other gadiform fishes known to date. FAO Fish. Synop., 10 (125): 1-442.

Günther, A. - 1887. Report on the deep-sea fishes collected by
H.M.S. Challenger during the years 1873-76. Challenger Rep., Zool., 22: 1-268.

Howes, G.J. - 1991. Biogeography of gadoid fishes. J. Biogeogr., 18: 595-622.

Kong U., I and R. Meléndez C. - 1991. Estudio taxonómico y sistemático de la ictiofauna de aguas profundas capturadas entre Arica e Isla Mocha (18³0'-38³0' Lat. S). Estud. Oceanol., 10: $1-81$.

Meléndez, R.C. and D.F. Markle. - 1997. Phylogeny and zoogeography of Laemonema and Guttigadus (Pisces: Gadiformes: Moridae). Bull. Mar. Sci., 61(3): 593-670.

Nakamura, I. - 1986. Moridae, Lepidion ensiferus. In: I. Nakamura (ed.), Important fishes trawled of Patagonia, pp. 110-111. Japan Marine Fisheries Resource Research Center, Tokyo.

Nakaya, K., K. Amaoka and K. Abe. - 1980. A review of the genus Lepidion (Gadiformes, Moridae) from the north-western Pacific. Jap. J. Ichthyol., 27(1): 41-47.

Paulin, C.D. - 1983. A revision of the family Moridae (Pisces: Anacanthini) within the New Zealand region. Natl. Mus. New Zealand Rec., 2(9): 81-126.

Paulin, C.D. - 1984. First record of Lepidion inosimae (Günther) and L. schmidti Svetovidov (Pisces: Moridae) from New Zealand. New Zealand J. Zool., 11: 59-62.

Small, G.J. - 1981. A review of the bathyal fish genus Antimora (Moridae: Gadiformes). Proc. California Acad. Sci., 42(13): 341-348.

Templeman, W. - 1970. A review of the morid fish genus Lepidion of the North Atlantic with first records of Lepidion eques from the western North Atlantic. J. Fish. Res. Brd Canada, 27: 457-489. 